\title{
Adhesion patterns of commensal and pathogenic Escherichia coli from humans and wild animals on human and porcine epithelial cell lines
}

Ulrike Frömmel ${ }^{1 *}$, Alexander Böhm¹, Jörg Nitschke ${ }^{1}$, Jörg Weinreich ${ }^{1}$, Julia Groß¹, Stefan Rödiger ${ }^{1}$, Thomas Wex², Hermann Ansorge ${ }^{3}$, Olaf Zinke ${ }^{4}$, Christian Schröder ${ }^{1}$, Dirk Roggenbuck ${ }^{1,5}$ and Peter Schierack ${ }^{1}$

\begin{abstract}
Background: Different strategies of colonization or infection by E. coli result in formation of certain adhesion patterns which help also in classifying intestinal E. coli into pathotypes. Little is known about adhesion patterns and host- and tissue adaption of commensal E. coli and about E. coli originating in clinically healthy hosts carrying pathotype-specific virulence-associated genes.

Findings: Adhesion pattern of E. coli $(n=282)$ from humans and from 18 animal species were verified on intestinal human Caco-2 and porcine IPEC-J2 cells and, furthermore, for comparison on human urinary bladder 5637, porcine kidney PK-15 epithelial and HEp-2 cells. The analysis was carried out on 150,000 images of adhesion assays. Adhesion patterns were very diverse; 88 isolates were completely non-adherent, whereas 194 adhered to at least one cell line with the dominant adhesion patterns "diffusely distributed" and "microcolony formation". Adhesion patterns "chains" and "clumps" were also visible. Chain formation was mediated by the presence of epithelial cells. Clump formation was very specific on only the 5637 cell line. All enteropathogenic $\left(e a e^{+}\right)$E. coli $(E P E C ; n=14)$ were able to form microcolonies which was cell line specific for each isolate. Most EPEC formed microcolonies on intestinal IPEC-J2 and Caco-2 but several also on urinary tract cells. Shigatoxin-producing $\left(s t x^{+}\right)$E. coli $(n=10)$ showed no specific adhesion patterns.
\end{abstract}

Conclusions: E. coli isolates were highly diverse. Commensal and pathogenic isolates can adhere in various forms, including diffuse distribution, microcolonies, chains and clumps. Microcolony formation seems to be a global adhesion strategy also for commensal E. coli.

Keywords: E. coli, Adhesion patterns, Virulence-associated genes, Pathotypes, IPEC-J2, PK-15, Caco-2, 5637, HEp-2

\section{Findings}

\section{Background}

The occurrence of bacterial virulence factors coded by virulence-associated genes (VAGs) indicates different host infection mechanisms and adhesion patterns, and can be used to define intestinal E. coli pathotypes [1]. Pathotypespecific VAGs frequently detected in $E$. coli from diarrheic hosts can also be found in $E$. coli from clinically healthy hosts $[2,3]$. It is neither known if such isolates display adhesion patterns similar to their pathogenic counterparts

\footnotetext{
*Correspondence: ulrike.froemmel@gmx.de

'Brandenburg Technical University Cottbus/Senftenberg, Faculty of Natural Sciences, Großenhainer Str. 57, D-01968, Senftenberg, Germany

Full list of author information is available at the end of the article
}

nor whether their adhesion or infection patterns are host-specific and tissue-specific. Moreover, no information is available regarding host- or tissue-specific adhesion patterns of $E$. coli without VAGs (commensals). We analyzed adhesion patterns of 282 intestinal $E$. coli isolates on four epithelial cell lines. Due to such a large amount of isolates, we created an automatic imaging method based on fluorescence microscopy.

\section{Results \\ Adhesion patterns of $E$. coli}

Of 282 E. coli, 28 isolates (9.9\%) carried at least one VAG which defined 14 enteropathogenic (EPEC), 10 Shigatoxinproducing (STEC), 3 enterotoxigenic (ETEC) and 1 daa $\mathrm{D}^{+}$

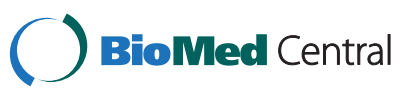


diffusely adherent E. coli (DAEC) (Table 1; [4]). Two EPEC were typical (tEPEC, $\mathrm{pEAF}^{+}$) and 12 were atypical EPEC (aEPEC, pEAF ${ }^{-}$). Most isolates (68.8\%) adhered to at least one cell line but $31.2 \%$ of isolates were non-adherent. Adhesion and pattern formation was most present on Caco-2, followed by IPEC-J2, 5637 and PK-15 cells (Table 2 and 3).

We identified four adhesion pattern of all E. coli: (i) diffusely distributed single bacteria; (ii) microcolonies; (iii) chains; and (iv) clumps (Figure 1). Isolates formed one adhesion pattern on one cell line only (cell line-specific), on all cell lines (both, host cell-unspecific and tissue-unspecific), on urinary tract or intestinal cells (tissue-specific) or on human or porcine cells (host cell-specific) (Table 2). There was no species-specific adhesion pattern which means that $E$. coli isolates from one animal host displayed diverse adhesion patterns on one cell line (Table 3). Two isolates formed clumps on cell line 5637 (Figure 1C) but were distributed diffusely or formed microcolonies on other cell lines. Chain formation could be identified in eleven isolates and was unspecific. Chain formation was inducible by cell culture medium as well as by the epithelial cells themselves (Figure 2).

\section{Associations between pathotypes and adhesion patterns} EPEC: We tested the microcolony formation of EPEC on intestinal and urinary tract cells and on the model cell line HEp-2. All eae $\mathrm{A}^{+}$isolates formed microcolonies on at least two cell lines but no isolate formed microcolonies on all cell lines. aEPEC formed microcolonies on IPEC-J2 (10 aEPEC), Caco-2 (10), HEp-2 (7), PK-15 (2) and 5637 cells (2) (Figure 3) STEC: All STEC were non-adherent to any tested cell line with the exception of 6 STEC; 5 were low adherent on Caco- 2 cells; one was low adherent on human cells ETEC: A consistent adhesion pattern was not observed for the three ETEC daaD ${ }^{+}$DAEC. The one human daa $\mathrm{D}^{+}$DAEC adhered diffusely to human intestinal and urinary tract and also to HEp- 2 cells but did not adhere to porcine cells.

\section{Discussion and conclusion}

In contrast to conventional adhesion studies which include relatively low numbers of isolates and cell lines, the present study included $282 \mathrm{E}$. coli isolates and their adhesion patterns on four cell lines. To handle such large sample numbers, assays were adapted to the 96-well cell culture format and to the fluorescence microscopy-based technology [5].

\section{Adhesion patterns of commensals}

The expression of different bacterial adhesins binding on host cell receptors drives bacterial tissue and host specificity $[6,7]$. We demonstrated that most isolates had different adhesion patterns on different cell lines. However, there were also isolates which had one adhesion pattern on all cell lines. This indicates the broad spectrum of adhesin-receptor interactions of E. coli in the intestinal and urinary tract. Microcolony formation was more unspecific than diffuse distribution, thus indicating that microcolony formation is less dependent on cell type specific receptors or response.

It is well known that EPEC forms microcolonies. This has also been demonstrated in the case of our 14 eae $^{+}$ isolates. However, there were other 61 isolates which also formed microcolonies but were intimin-negative according to our PCR which was able to detect all known intimin types. This shows that microcolony formation is more of a global adhesion and colonization strategy which ensues resistance to environmental or host immunological stresses [8,9].

$E$. coli chain formation was just recently published by Gioppo et al. (2000) and Vejborg and Klemm (2009) $[10,11]$. Our isolates did not form chains in pure LB medium but in cell culture media or on epithelial cells which is in contrast to these previous studies [11]. This, and the fact that chains were longer on cells than chains in cell culture media alone, showed that epithelial cells mediated $E$. coli chain formation.

Two isolates of our study exhibited a very unique adhesion pattern on 5637 cells only. They formed large clumps of several thousand bacteria which was not been described so far. We assume these two isolates have a high potential for biofilm formation.

\section{Adhesion patterns of intestinal pathogens}

EPEC: All 14 intimin-positive isolates formed microcolonies on at least two cell lines verifying that these isolates are indeed EPEC. Host cell-unspecific and tissue-unspecific microcolony formation of some isolates showed that microcolony formation can be a universal infection mechanism. Other isolates showed tissue or host tropism which often depends on different intimin subtypes. Interestingly, several EPEC formed microcolonies on urinary tract epithelial cells, a fact which has not previously been recorded and which might contribute to E. coli urinary tract infections. Finally, IPEC-J2 turned out to be a better model cell line for the verification of the EPEC phenotype than HEp-2 cells and may represent an additional valuable diagnostic tool. STEC: In general, the adhesion of STEC isolates to any tested cell line was very low, supporting the non-adhesive infection mechanism of STEC [12]. ETEC and DAEC: As we detected only 3 ETEC and only 1 DAEC, we have not gone into any discussion about adhesion pattern specificity here.

In conclusion, adhesion patterns as well as host and tissue specificity varied broadly between isolates. Since diffuse adherence was also detected for many commensal $E$. coli, any characterization of pathogenic DAEC based solely on the determination of pattern formation would 
Table 1 Species of isolated E. coli and detected intestinal E. coli pathotypes

\begin{tabular}{|c|c|c|c|c|c|c|c|}
\hline Species & & Number of $E$. coli isolates & aEPEC & tEPEC & STEC & ETEC & $\overline{\text { DAEC }}$ \\
\hline \multicolumn{8}{|l|}{ Mammals } \\
\hline Homo sapiens & Human & $19^{(a)}$ & - & - & 1 & - & 1 \\
\hline Sus scrofa domestica & Domestic pig & $22^{(b)}$ & - & - & - & 1 & - \\
\hline Capreolus capreolus & Roe deer & $23^{(c, d)}$ & - & - & 9 & 1 & - \\
\hline Erinaceus europaeus & European hedgehog & $22^{(c)}$ & - & 1 & - & - & - \\
\hline Lepus europaeus & European hare & $8^{(c)}$ & 3 & - & - & - & - \\
\hline Lutra lutra & European otter & $7^{(c)}$ & - & - & - & - & - \\
\hline Martes sp. & Marten & $19^{(\mathrm{c})}$ & 3 & - & - & - & - \\
\hline Meles meles & European badger & $7^{(c)}$ & 1 & - & - & - & - \\
\hline Mus musculus & House mouse & $9^{(c)}$ & - & - & - & - & - \\
\hline Oryctolagus cuniculus & European rabbit & $6^{(c)}$ & - & 1 & - & - & - \\
\hline Procyon lotor & Raccoon & $22^{(c)}$ & 2 & - & - & - & - \\
\hline Rattus norvegicus & Brown rat & $4^{(c)}$ & - & - & - & - & - \\
\hline Sciurus vulgaris & Red squirrel & $17^{(\mathrm{c})}$ & 2 & - & - & - & - \\
\hline Sus scrofa & Wild boar & $22^{(c, d)}$ & - & - & - & - & - \\
\hline Vulpes vulpes & Red fox & $21^{(c)}$ & 1 & - & - & 1 & - \\
\hline \multicolumn{8}{|l|}{ Birds } \\
\hline Accipiter nisus & Eurasian sparrowhawk & $13^{(c)}$ & - & - & - & - & - \\
\hline Asio otus & Long-eared owl & $5^{(c)}$ & - & - & - & - & - \\
\hline Buteo buteo & Common buzzard & $14^{(\mathrm{c})}$ & - & - & - & - & - \\
\hline Turdus merula & Common blackbird & $22^{(\mathrm{c})}$ & - & - & - & - & - \\
\hline
\end{tabular}

(a) Isolates sampled by Thomas Wex, Otto-von-Guericke University, Magdeburg, Germany; ${ }^{(b)}$ Isolates collected from eighteen different pig production units in Eastern Germany in the years 2009/2010;

(c) Isolates collected from dead animals in the LausitzLusatia), a region in southeastern Germany, which were directly collected as accident victims or which were delivered to the Senckenberg MuseumGörlitz, Germany) and the Museum der WestlausitzKamenz, Germany) between 2007 and 2011;

(d) Isolates sampled during several hunts between 2007 and 2010.

Table 2 E. coli adhesion patterns: cell line, tissue, host cell specificity

\begin{tabular}{|c|c|c|c|c|c|}
\hline Adhesion pattern specificity & Cell lines & Diffusely distributed & Micro-colonies & Chains & Various pattern \\
\hline \multirow[t]{4}{*}{ Cell line } & Caco-2 & 28 & 6 & 1 & - \\
\hline & IPEC-J2 & 12 & 3 & - & - \\
\hline & 5637 & 10 & - & - & - \\
\hline & PK-15 & 1 & - & - & - \\
\hline \multirow[t]{2}{*}{ Tissue } & Intestinal epithelium (Caco-2, IPEC-J2) & 16 & 9 & - & 1 \\
\hline & Urinary epithelium (5637, PK-15) & 1 & - & - & - \\
\hline \multirow[t]{2}{*}{ Host cell } & Human (Caco-2, 5637) & 9 & 8 & - & 1 \\
\hline & Porcine (IPEC-J2, PK-15) & 3 & 3 & - & - \\
\hline \multirow[t]{2}{*}{ Unspecific } & All cell lines & 8 & 20 & 3 & 12 \\
\hline & Other groups of cell lines & 21 & 8 & 2 & 8 \\
\hline
\end{tabular}

Classified are isolates which adhered with a distinct pattern (diffusely distributed, microcolonies, chains) to at least one cell line ( $\mathrm{n}=172$ ), and isolates with different adhesion patterns to the four cell lines (various pattern, $n=22)$. Non-adherent isolates $(n=88)$ were excluded. Most distinct pattern-forming isolates were diffusely distributed on at least one cell line $(n=109)$ followed by microcolony forming isolates $(n=57)$. "Other groups of cell lines" includes isolates with adhesion patterns on the following cell lines: 1) Caco-2 and 5637 and IPEC-J2; 2) Caco-2 and 5637 and PK-15; 3) Caco-2 and IPEC-J2 and PK-15; 4) 5637 and IPEC-J2 and PK-15; 5) Caco-2 and PK-15; 6) 5637 and IPEC-J2. 
Table 3 Number of E. coli isolates from human and 18 animal species and its adhesion patterns on Caco-2, IPEC-J2, 5637 and PK-15

Human Domestic Roe Europ. Europ. Europ. Mar Europ. House Europ. Rac Brown Red Wild Red Eurasian Long-eared Common Common sum pig deer hedgehog hare otter ten badger mouse rabbit coon rat squirrel boar fox sparrow owl buzzard blackbird

\begin{tabular}{|c|c|c|c|c|c|c|c|c|c|c|c|c|c|c|c|c|c|c|c|c|}
\hline & \multirow[b]{2}{*}{19} & & \multirow{2}{*}{23} & & \multirow[b]{2}{*}{8} & \multirow[b]{2}{*}{7} & \multirow[b]{2}{*}{19} & \multirow[b]{2}{*}{7} & \multirow[b]{2}{*}{9} & \multirow[b]{2}{*}{6} & \multirow[b]{2}{*}{22} & \multirow[b]{2}{*}{4} & \multirow[b]{2}{*}{17} & \multirow[b]{2}{*}{22} & \multirow[b]{2}{*}{21} & \multirow[b]{2}{*}{13} & & \multirow[b]{2}{*}{14} & & \\
\hline Isolates & & & & & & & & & & & & & & & & & 5 & & 22 & 282 \\
\hline \multicolumn{21}{|l|}{ Caco-2 } \\
\hline Microcolonies & 5 & 4 & 3 & 6 & 4 & - & 6 & 2 & - & 1 & 6 & 2 & 8 & 1 & 4 & - & - & 2 & 8 & 62 \\
\hline Chains & - & - & 2 & - & - & - & 3 & - & - & - & - & - & - & 2 & - & - & - & 1 & 1 & 9 \\
\hline Distributed & 5 & 5 & 5 & 1 & 3 & 5 & 2 & 4 & 3 & 4 & 8 & 1 & 8 & 1 & 3 & 8 & 3 & 7 & 8 & 84 \\
\hline Non-adherent & 9 & 13 & 13 & 15 & 1 & 2 & 8 & 1 & 6 & 1 & 8 & 1 & 1 & 18 & 14 & 5 & 2 & 4 & 5 & 127 \\
\hline \multicolumn{21}{|l|}{ IPEC-J2 } \\
\hline Microcolonies & 3 & 3 & 2 & 6 & 3 & - & 7 & 2 & - & 2 & 2 & 2 & 5 & - & 6 & 1 & - & 1 & 7 & 52 \\
\hline Chains & - & - & - & 1 & - & - & - & - & - & - & - & - & - & 2 & - & - & - & 1 & 1 & 5 \\
\hline Distributed & 7 & 4 & 3 & 5 & - & 2 & 7 & 2 & 3 & 1 & 1 & - & 3 & 1 & - & 3 & 1 & 3 & 9 & 55 \\
\hline Non-adherent & 9 & 15 & 18 & 10 & 5 & 5 & 5 & 3 & 6 & 3 & 19 & 2 & 9 & 19 & 15 & 9 & 4 & 9 & 5 & 170 \\
\hline \multicolumn{21}{|l|}{5637} \\
\hline Microcolonies & 1 & 2 & 4 & 5 & 1 & - & 5 & 1 & - & 1 & 4 & 2 & 4 & 1 & 3 & - & - & 1 & 4 & 39 \\
\hline Chains & - & - & 1 & - & - & - & 1 & - & - & - & - & - & - & 2 & - & - & - & - & 2 & 6 \\
\hline Clumps & 1 & - & - & - & - & - & - & - & - & - & - & - & 1 & - & - & - & - & - & - & 2 \\
\hline Distributed & 6 & 5 & 2 & 2 & 2 & 2 & 3 & - & - & - & 3 & - & 3 & 5 & 3 & 2 & 1 & 2 & 2 & 43 \\
\hline Non-adherent & 11 & 15 & 16 & 15 & 5 & 5 & 10 & 6 & 9 & 5 & 15 & 2 & 9 & 14 & 15 & 11 & 4 & 11 & 14 & 192 \\
\hline \multicolumn{21}{|l|}{ PK-15 } \\
\hline Microcolonies & 6 & 2 & 3 & 2 & 2 & - & 4 & 1 & - & 2 & 2 & 2 & 2 & - & 4 & - & - & 1 & 6 & 39 \\
\hline Chains & - & - & 1 & - & - & - & 1 & - & - & - & - & - & - & 2 & - & - & - & 1 & 1 & 6 \\
\hline Distributed & 2 & 3 & 1 & 1 & 1 & - & 3 & 1 & 1 & 2 & - & 1 & 3 & 1 & 4 & 3 & 1 & 5 & 1 & 34 \\
\hline Non-adherent & 11 & 17 & 18 & 19 & 5 & 7 & 11 & 5 & 8 & 2 & 20 & 1 & 12 & 19 & 13 & 10 & 4 & 7 & 14 & 203 \\
\hline
\end{tabular}

Distributed $=$ diffuse adherent and diffusely distributed. 

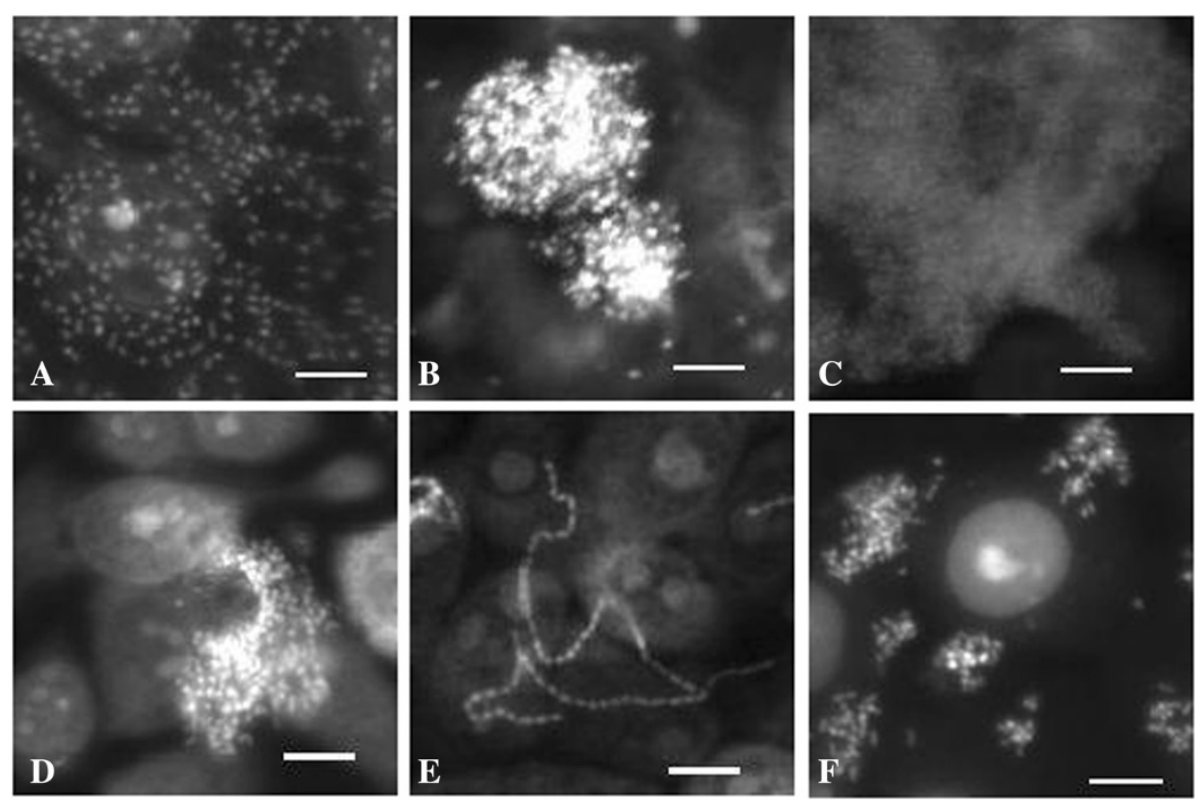

Figure $1 \mathrm{E}$. coli adhesion patterns of commensal E. coli and tEPEC. Fluorescent images of epithelial cells and adherent bacteria which were stained with propidium iodide are depicted. A) E. coli isolate from a domestic pig adhering diffusely distributed to IPEC-J2 cells. B) E. coli isolate from a European hare forming microcolonies on Caco-2 cells. C) E. coli isolate from a human forming clumps on 5637 cells. D) E. coli isolate from a common blackbird forming microcolonies on 5637 cells. E) E. coli isolate from a wild boar forming chains on PK-15 cells. F) tEPEC isolate from a European hedgehog forming microcolonies on 5637 cells. Scale: $10 \mu \mathrm{m}$.
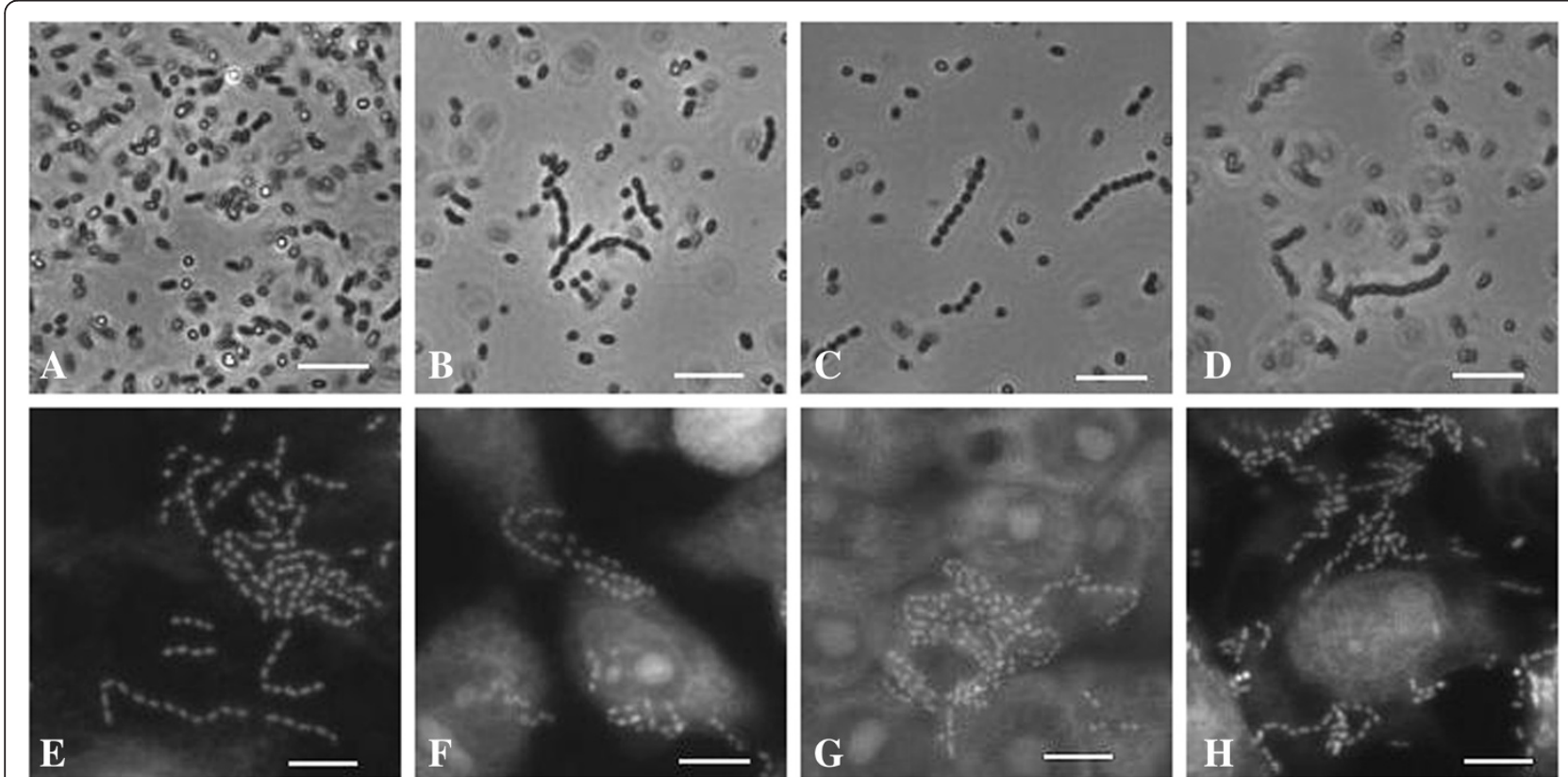

Figure $\mathbf{2}$ Chain formation of one $E$. coli isolate from a common blackbird. Fluorescence images were taken after incubation in LB medium (overnight), cell culture media (four hours) and after incubation on epithelial cells (four hours). Chain formation is induced by cell culture media, and stimulated by epithelial cells. Isolate in A) LB medium: no chains, B) Caco-2 cell culture medium, C) 5637 cell culture medium, D) IPEC-J2 and PK-15 cell culture medium. Isolate after four-hour adhesion assay with cell culture media on E) Caco-2, F) 5637, G) PK-15 cells. H) Isolate after four-hour adhesion assay with LB media on IPEC-J2 cells. A-D) Phase contrast microscopy. E-H) Fluorescence microscopy. Scale: $10 \mu \mathrm{m}$. 


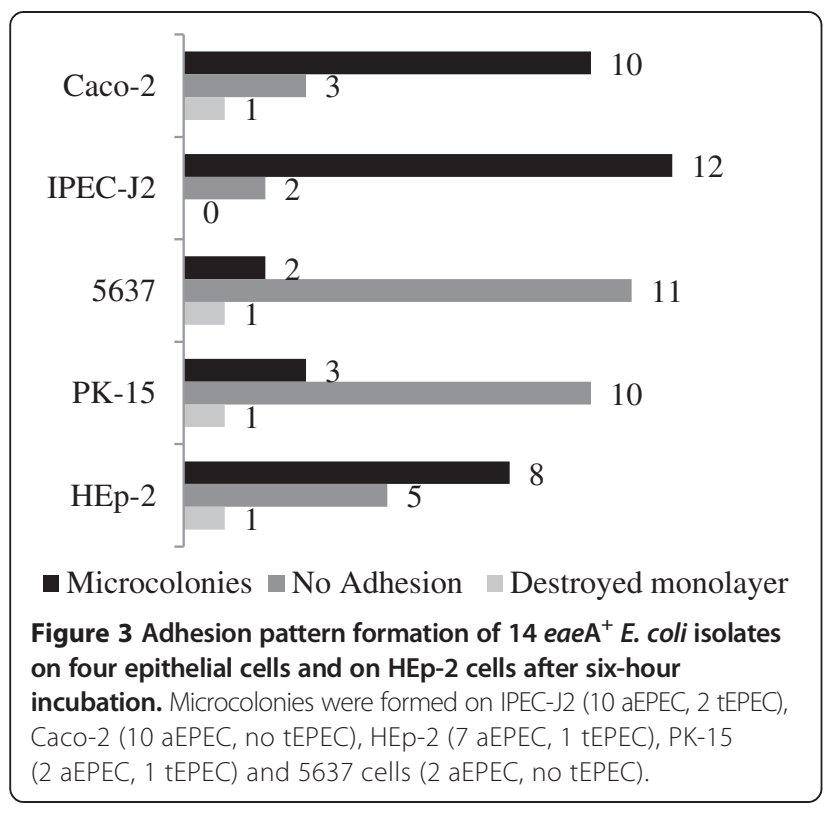

appear to be unsuitable. Since many commensal isolates also formed microcolonies, this adhesion pattern must be recognized as a global colonization strategy.

\section{Methods}

\section{Bacterial isolates}

Isolates are listed in Table 1. Identification and confirmation of $E$. coli is extensively described elsewhere [4,13-15]. Hemolytic isolates were excluded from analysis as they destroy cell monolayers. For human samples, sample collection was performed by individuals themselves using sterile collection tubes. The samples represented the negative controls of a clinical study. Participants were prospectively informed about the potential usage of redundant stool samples for research purpose; no written informed consent was obtained from patients. All associated information relating to these samples was anonymous. This study was approved by the Ministry of Environment, Health and Consumer Protection of the Federal State of Brandenburg, Germany (V3-2347-8-39-1-2011).

\section{Multiplex PCR assay}

$E$. coli pathotyping based on the occurrence of VAGs: tEPEC (eae $\left.{ }^{+} \mathrm{pEAF}^{+}\right)$; aEPEC $\left(e a e \mathrm{~A}^{+} \mathrm{pEAF}^{-}\right)$; STEC

Table 4 Primers for VAGs of $E$. coli

\begin{tabular}{|c|c|c|c|c|c|}
\hline \multicolumn{2}{|l|}{ Genes } & $\begin{array}{l}\text { Primer and probe sequences } \\
\text { (5' } 3 \text { f: forward; r: reverse) }\end{array}$ & Fragment length & Accession & Source of primer \\
\hline \multicolumn{6}{|c|}{ Multiplex PCR } \\
\hline \multirow[t]{2}{*}{$\mathrm{ipaH}$} & $f$ & GTTCCTTGACCGCCTTTCCGATACCGTC & 619 & M32063 & {$[17]$} \\
\hline & $r$ & GCCGGTCAGCCACCCTCTGAGAGTAC & & & \\
\hline \multirow[t]{2}{*}{ daaD } & $f$ & TGAACGGGAGTATAAGGAAGATG & 371 & AY525531.1 & {$[17]$} \\
\hline & r & GTCCGCCATCACATCAAAA & & & \\
\hline \multirow[t]{2}{*}{ eltB } & f & TCTCTATGTGCATACGGAGC & 322 & EU113252.1 & {$[17]$} \\
\hline & $r$ & CCATACTGATTGCCGCAAT & & & \\
\hline \multirow[t]{2}{*}{ eaeA } & $f$ & CCTGGTTACAACATTATGGAACG & 287 & AJ308550.1 & [4] \\
\hline & $r$ & TGAAATAGTCTCGCCAGTATTCG & & & \\
\hline \multirow[t]{2}{*}{$s t \times 2$} & $f$ & GGCACTGTCTGAAACTGCTCC & 255 & FN252459 & {$[17]$} \\
\hline & $r$ & TCGCCAGTTATCTGACATTCTG & & & \\
\hline \multirow[t]{2}{*}{$\operatorname{aggR}$} & $f$ & CGTAAGCCGGGTATGAAAGA & 188 & Z32523.1 & [4] \\
\hline & $r$ & GCCAGTTCAGAAGCAGGAAC & & & \\
\hline \multirow[t]{2}{*}{ est1a } & $f$ & TTCCCCTCTITTAGTCAGTCAA & 159 & M25607.1 AY342057.1 & {$[17]$} \\
\hline & $r$ & GCAGGATTACAACACAATTCACAGCAG & & & \\
\hline \multirow[t]{2}{*}{$s t \times 1$} & $f$ & CTGGATITAATGTCGCATAGTG & 150 & HM367099.1 & {$[17]$} \\
\hline & $r$ & AGAACGCCCACTGAGATCATC & & & \\
\hline \multirow[t]{2}{*}{ est2 } & f & CTATTGCTACAAATGCCTATGC & 126 & M35586.1 & [4] \\
\hline & $r$ & CTCCAGCAGTACCATCTCTA & & & {$[18]$} \\
\hline \multicolumn{6}{|c|}{ Single PCR } \\
\hline \multirow[t]{2}{*}{ pEAF } & $f$ & CAGGGTAAAAGAAAGATGATAA & 397 & X76137.1 & {$[16]$} \\
\hline & $r$ & TATGGGGACCATGTATTATCA & & & \\
\hline
\end{tabular}


(stx 1 and/or $s t x 2)$; enterohemorrhagic E. coli/EHEC (stx 1 and/or stx 2 and eaeA); ETEC (elt $\mathrm{B}$ and/or est 1 and/or est2); DAEC (daaD); enteroaggregative $E$. coli/EAEC $(a g g \mathrm{R})$; enteroinvasive E. coli/EIEC (ipa $\mathrm{H})$; and commensals (no VAGs). The relevant multiplex PCR and PCR results were already described [4]. The pEAF-PCR was prepared according to Franke et al. 1994 [16]. Primers are listed in Table 4

\section{E. coli adhesion assays}

All cells were grown and adhesion assays were carried out as previously described [4,19]. E. coli were grown overnight to an $\mathrm{OD}_{600}$ of 0.8-1.2. Cells were inoculated with an infection dose of 62,500 bacteria per $\mathrm{mm}^{2}$ of a monolayer using a conversion of $3 \times 10^{8}$ bacteria $/ \mathrm{mL} / \mathrm{OD}_{600}$. After four hour incubation and washing with $1 x \mathrm{PBS}$, cells and adherent bacteria were fixed with $4 \%$ paraformaldehyde. Cells and bacteria were stained with propidium iodide $\left(10 \mu \mathrm{g} / \mathrm{mL}\right.$ in $\left.\mathrm{ddH}_{2} \mathrm{O}\right)$ and analyzed. All tests were repeated at least three times in triplicates. To verify the EPEC phenotype, eae $\mathrm{A}^{+}$isolates were carried out with six hours incubation time on epithelial cells including one additional washing step after three hours. The term "diffuse adherent" was used exclusively to refer to daa $\mathrm{D}^{+}$DAEC. A similar pattern of isolates not containing daaD was defined as "diffuse distributed".

\section{VideoScan/Aklides: fluorescence imaging technology}

The VideoScan technology implemented in the commercially available Aklides System (Medipan $\mathrm{GmbH}$, Dahlewitz/Berlin, Germany) is a versatile fluorescence microscope imaging technology which can be used to analyze fluorescent objects [4,5,20-22]. The VideoScan/ Aklides instrument automatically aligned itself to each well on a 96-well plate, focused on the cell monolayer surface and captured images [4]. A minimum cell monolayer area of $0.3 \mathrm{~mm}^{2}$ per well was investigated. All 150,000 images were visually analyzed for E. coli pattern formation. Isolates whose images resembled those of the negative control (cells without bacterial incubation) were defined as non-adherent.

\section{Competing interests}

Dirk Roggenbuck is a shareholder of GA Generic Assays GmbH and Medipan $\mathrm{GmbH}$. The remaining authors have no competing as well as non-financial interests.

\section{Authors' contribution}

UF carried out the in silico and in vitro studies, evaluated the images, analyzed the data, and drafted and wrote the manuscript. AB and JN programmed the software for VideoScan. JW, JG, and SR participated in the in vitro analysis and in technical support. TW provided the human isolates; HA and OZ provided E. coli isolates from animals. CS and DR supported the work with scientific advice. PS supervised the work, managed the collection of isolates, wrote and revised the manuscript. All authors read and approved the final manuscript.

\section{Acknowledgements}

This work was supported by InnoProfile IP 03 IP 611 funded by the Bundesministerium für Bildung und Forschung (BMBF, Germany).

\section{Author details}

${ }^{1}$ Brandenburg Technical University Cottbus/Senftenberg, Faculty of Natural Sciences, Großenhainer Str. 57, D-01968, Senftenberg, Germany.

2Otto-von-Guericke University, Magdeburg, Germany. ${ }^{3}$ Senckenberg Museum, Görlitz, Germany. ${ }^{4}$ Museum der Westlausitz, Kamenz, Germany. ${ }^{5} \mathrm{GA}$ Generic Assays $\mathrm{GmbH}$, Dahlewitz, Germany.

Received: 25 July 2013 Accepted: 19 October 2013

Published: 4 November 2013

\section{References}

1. Kaper JB, Nataro JP, Mobley HL: Pathogenic Escherichia coli. Nat Rev Microbiol 2004, 2(2):123-140.

2. Schierack P, Walk N, Reiter K, Weyrauch KD, Wieler LH: Composition of intestinal Enterobacteriaceae populations of healthy domestic pigs. Microbiology 2007, 153(Pt 11):3830-3837.

3. Beutin L, Marches O, Bettelheim KA, Gleier K, Zimmermann S, Schmidt H, Oswald E: HEp-2 cell adherence, actin aggregation, and intimin types of attaching and effacing Escherichia coli strains isolated from healthy infants in Germany and Australia. Infect Immun 2003, 71(7):3995-4002.

4. Frömmel U, Lehmann W, Rödiger S, Böhm A, Nitschke J, Weinreich J, Groß J, Roggenbuck D, Zinke $\mathrm{O}$, Ansorge $\mathrm{H}$, et al: Adhesion of human and animal Escherichia coli in association with their virulence-associated genes and phylogenetic origin. Appl Environ Microbiol 2013, 79(19):5814-5829.

5. Rödiger S, Schierack P, Böhm A, Nitschke J, Berger I, Frömmel U, Schmidt C, Ruhland M, Schimke I, Roggenbuck D, et al: A highly versatile microscope imaging technology platform for the multiplex real-time detection of biomolecules and autoimmune antibodies. Adv Biochem Eng Biotechnol 2013, 133:35-74

6. Nagy B, Fekete PZ: Enterotoxigenic Escherichia coli (ETEC) in farm animals. Vet Res 1999, 30(2-3):259-284.

7. Pizarro-Cerdá J, Cossart P: Bacterial adhesion and entry into host cells. Cell 2006, 124(4):715-727.

8. Anderson GG, Dodson KW, Hooton TM, Hultgren SJ: Intracellular bacterial communities of uropathogenic Escherichia coli in urinary tract pathogenesis. Trends Microbiol 2004, 12(9):424-430.

9. Donlan RM, Costerton JW: Biofilms: survival mechanisms of clinically relevant microorganisms. Clin Microbiol Rev 2002, 15(2):167-193.

10. Gioppo NM, Elias WP Jr, Vidotto MC, Linhares RE, Saridakis HO, Gomes TA, Trabulsi LR, Pelayo JS: Prevalence of HEp-2 cell-adherent Escherichia coli and characterisation of enteroaggregative $E$. coli and chain-like adherent $E$. coli isolated from children with and without diarrhoea, in Londrina, Brazil. FEMS Microbiol Lett 2000, 190(2):293-298.

11. Vejborg RM, Klemm P: Cellular chain formation in Escherichia coli biofilms. Microbiology 2009, 155(Pt 5):1407-1417.

12. Kolling GL, Matthews KR: Export of Virulence Genes and Shiga Toxin by Membrane Vesicles of Escherichia coli 0157:H7. Appl Environ Microbiol 1999, 65(5):1843-1848.

13. Merlino J, Siarakas S, Robertson GJ, Funnell GR, Gottlieb T, Bradbury R: Evaluation of CHROMagar Orientation for differentiation and presumptive identification of gram-negative bacilli and Enterococcus species. J Clin Microbiol 1996, 34(7):1788-1793.

14. Ewers C, Guenther S, Wieler LH, Schierack P: Mallard ducks - a waterfowl species with high risk of distributing Escherichia coli pathogenic for humans. Environ Microbiol Rep 2009, 1(6):510-517.

15. Schierack P, Römer A, Jores J, Kaspar H, Guenther S, Filter M, Eichberg J, Wieler $\mathrm{LH}$ : Isolation and characterization of intestinal Escherichia coli clones from wild boars in germany. Appl Environ Microbiol 2009, 75(3):695-702.

16. Franke J, Franke S, Schmidt H, Schwarzkopf A, Wieler LH, Baljer G, Beutin L, Karch H: Nucleotide sequence analysis of enteropathogenic Escherichia coli (EPEC) adherence factor probe and development of PCR for rapid detection of EPEC harboring virulence plasmids. J Clin Microbiol 1994, 32(10):2460-2463.

17. Guion CE, Ochoa TJ, Walker CM, Barletta F, Cleary TG: Detection of diarrheagenic Escherichia coli by use of melting-curve analysis and real-time multiplex PCR. J Clin Microbio/ 2008, 46(5):1752-1757. 
18. Casey TA, Bosworth BT: Design and evaluation of a multiplex polymerase chain reaction assay for the simultaneous identification of genes for nine different virulence factors associated with Escherichia coli that cause diarrhea and edema disease in swine. J Vet Diagn Invest 2009, 21(1):25-30.

19. Schierack P, Kleta S, Tedin K, Babila JT, Oswald S, Oelschlaeger TA, Hiemann R, Paetzold S, Wieler LH: E. coli Nissle 1917 affects Salmonella adhesion to porcine intestinal epithelial cells. PLoS One 2011, 6(2):e14712.

20. Egerer K, Roggenbuck D, Hiemann R, Weyer MG, Buttner T, Radau B, Krause R, Lehmann B, Feist E, Burmester GR: Automated evaluation of autoantibodies on human epithelial-2 cells as an approach to standardize cell-based immunofluorescence tests. Arthritis Res Ther 2010, 12(2):R40.

21. Grossmann K, Roggenbuck D, Schröder C, Conrad K, Schierack P, Sack U: Multiplex assessment of non-organ-specific autoantibodies with a novel microbead-based immunoassay. Cytometry A 2011, 79(2):118-125.

22. Roggenbuck D, Reinhold D, Hiemann R, Anderer U, Conrad K: Standardized detection of anti-ds DNA antibodies by indirect immunofluorescence - a new age for confirmatory tests in SLE diagnostics. Clin Chim Acta 2011, 412:2011-2012.

doi:10.1186/1757-4749-5-31

Cite this article as: Frömmel et al: Adhesion patterns of commensal and pathogenic Escherichia coli from humans and wild animals on human and porcine epithelial cell lines. Gut Pathogens 2013 5:31.

\section{Submit your next manuscript to BioMed Central and take full advantage of:}

- Convenient online submission

- Thorough peer review

- No space constraints or color figure charges

- Immediate publication on acceptance

- Inclusion in PubMed, CAS, Scopus and Google Scholar

- Research which is freely available for redistribution 